Gelanggang Olahraga: Jurnal Pendidikan Jasmani dan Olahraga

Volume 1, Nomor 2, Januari-Juni 2018

e-ISSN : 2597-6567

p-ISSN : 2614-607X

DOI : https://doi.org/10.31539/jpjo.v1i2.133

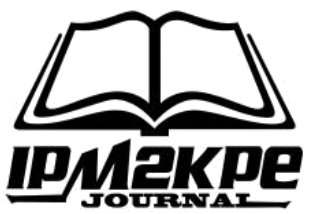

\title{
KONTRIBUSI VO2 MAX TERHADAP KEMAMPUAN RENANG GAYA DADA 200 METER
}

\author{
Erick Salman \\ Universitas Negeri Padang \\ ericksalman.s.si@gmail.com
}

\begin{abstract}
ABSTRAK
Tujuan penelitian ini adalah untuk melihat kontribusi VO2 Max terhadap kemampuan renang gaya dada $200 \mathrm{M}$. Jenis penelitian ini adalah korelasional yaitu untuk melihat kontribusi VO2 Max terhadap kemampuan renang gaya dada 200 M. Populasi pada penelitian ini adalah mahasiswa Jurusan Kesehatan dan Rekreasi Fakultas Ilmu Keolahragaan Universitas Negeri Padang tahun 2013 yang mengambil mata kuliah renang yang berjumlah 112 orang. Teknik pengambilan sampel dalam penelitian ini yaitu random sampling yang diambil 50\% di tiap-tiap kode seksi dengan jumlah hasil sampel semuanya 54 orang. Pengumpulan data dilakukan dengan melaksanakan tes VO2 Max dan tes kemampuan renang gaya dada 200 meter. Analisa data dan pengujian hipotesis penelitian menggunakan teknik analisis korelasi sederhana dengan taraf signifikan $\alpha=0,05$. Untuk mencari kontribusi menggunakan rumus $\mathrm{r}^{2} \mathrm{x} 100 \%$. Berdasarkan hasil penelitian, dapat dilihat perbandingan $\mathrm{r}$ hitung $(0,382)>\mathrm{r}$ tabel $(0,261)$ maka data menunjukkan terdapat hubungan antara VO2 Max dengan kemampuan renang gaya dada 200 meter dan juga hasil $t_{\text {hitung }}(3,24)>t_{\text {tab }}(1,675)$, maka data menunjukkan terdapatnya hubungan yang signifikansi antara VO2 Max dengan kemampuan renang gaya dada 200 meter. Berdasarkan hasil penelitian menunjukkan terdapatnya kontribusi VO2 Max terhadap kemampuan renang gaya dada 200 meter mahasiswa Jurusan Kesehatan Rekreasi FIK UNP dengan tingkat persentase sebesar $14,59 \%$.
\end{abstract}

Kata Kunci : Renang Gaya Dada, VO2 Max

\section{ABSTRACT}

The purpose of this study is to see the contribution of VO2 Max to the ability of breaststroke pool $200 \mathrm{M}$. This type of research is correlational is to see the contribution of VO2 Max to the ability of breaststroke pool $200 \mathrm{M}$. The population in this study are students of the Department of Health and Recreation Faculty of Sport Sciences University Negeri Padang in 2013 that took the swimming course totaling 112 people. Sampling technique in this research is random sampling taken $50 \%$ in each of the code section with the total sample result all 54 people. The data was collected by carrying out the VO2 Max test and a 200 meter breaststroke capability test. Data analysis and hypothesis testing research using simple correlation analysis technique with significant level $\alpha=0,05$. To find contributions using the formula $r 2 \times 100 \%$. Based on the results of the study, it 
can be seen the comparison of $r$ count (0.382)> $r$ table (0.261) then the data shows there is a relationship between VO2 Max with 200 meter breaststroke ability and also tcount (3.24)> ttab (1,675) showed a significant relationship between VO2 Max and a 200-meter breaststroke ability. Based on the results of the study showed the contribution of VO2 Max to the 200 meter breaststroke proficiency of the students of Department of Health Recreation FIK UNP with the percentage of $14.59 \%$.

Keywords: Pool Style Chest, VO2 Max

\section{PENDAHULUAN}

Renang gaya dada 200 meter adalah olahraga yang dilakukan didalam air dalam jarak 200 meter yang yang memilki waktu relatif cukup lama dalam melakukannya, olahraga ini membutuhkan sistem energi daya tahan aerobik, waktu rantang yang dibutuhkan 2 menit ke atas. Diperkuat pendapat Bafirman, (2008) "olahraga ini terdapat pada kategori daya tahan sedang/ menengah (2 sampai 8 menit) kemampuan ini disebut juga kapasitas anaerobik atau juga dapat dikatakan aerobik". Dimana olahraga ini juga sangat penting bagi setiap individu karena dapat menyelamatkan diri sendiri ketika berada di air. Renang adalah olahraga menyehatkan, sebab hampir semua otot tubuh bergerak sehingga seluruh otot berkembang dengan baik. Dalam undang-undang tentang sistem keolahragaan nasional No. 3 pasal 4 tahun 2005 menyatakan bahwa keolahragaan nasional bertujuan memelihara dan meningkatkan kesehatan dan kebugaran , prestasi, kualitas manusia, menanamkan nilai moral dan ahlak mulia, sportivitas, disiplin, mempererat dan membina persatuan dan kesatuan bangsa memperkukuh ketahanan nasional, serta mengangkat harkat martabat dan kehormatan bangsa.

Dalam olahraga renang gaya dada 200 meter sangat di pengaruhi sekali oleh kemampuan mengambil oksigen sebanyak mungkin yaitu kemampuan $V O 2$ Maxnya. Menurut menurut Sumosardjuno (1996) mengatakan "VO2 Max menggambarkan tingkat aktivitas badan untuk mendapat oksigen, mengirimkan ke otot, ke sel lain dan menggunakannya dalam pengadaan energi, membuang sisa metabolisme yang menghambat aktivitas fisik'. Pengertian ini bukan saja mengatakan bahwa VO2 Max sebagai tingkat kemampuan badan/fisik untuk mengambil oksigen, tetapi juga mengirimkan ke otot-otot yang bekerja serta membantu pembuangan sisa metabolisme dan tidak itu saja VO2 Max juga salah satu faktor untuk menunjang prestasi. Diperkuat oleh pendapat Arsil (1999) yang menyatakan "volume oksigen maximal merupakan salah satu faktor penting untuk menunjang prestasi atlet, lebih-lebih pada atlet dari cabang olahraga yang termasuk olahraga daya tahan (endurance event)".

Dalam melakukan renang gaya dada yang paling utama diperhatikan adalah penguasaan teknik yang benar, karena teknik yang benar merupakan pondasi untuk pencapaian hasil yang optimal. Dengan teknik yang benar seseorang perenang dapat memperkecil hambatan, memperkuat daya luncur dan juga mempertahankan dalam kecepatan untuk sampai ke finise. Menurut Syafruddin, (2004) Latihan teknik yang tepat adalah salah satu penunjang untuk menjadi juara, karena dengan teknik yang benar dapat memperkecil hambatan. 
Dan juga tidak melupakan faktor-faktor kondisi fisik yang sangat berhubungan dengan kemampuan renang gaya dada 200 meter.

Dalam olahraga renang gaya dada 200 meter ini dimana pada olahraga tersebut dominan berada pada kondisi fisik yang berkaitan daya tahan jantung paru pembuluh darah (cardiovaskuler), daya tahan otot yang bagus juga dengan ukuran panjang lengandan lebarnya telapak tangan juga sangat membantu , kekuatan tungkai, dan kekuatan otot perut,. Dimana lengan berfungsi sebagai pendayung sehingga semakin panjang lengan keseluruhan seseorang akan semakin jauh jangkauannya pada saat melakukan recovery (pemulihan) maksud dari pemulihan ini dimana pada saat kaki dalam posisi lurus dan sesudah selesai melakukan dorongan dekat pinggul dengan menekuk lutut, pada saat itu tangan mengayun atau melakukan jangkauan dengan gerakan bergantian, maka recovery juga sering di identikkan dengan istirahat dalam gerakan, sebenarnya hal ini tidak salah tapi penempatannya yang berbeda

Berdasarkan pemantauan peneliti yang dilihat di lapangan yang di peroleh sebagian mahasiswa masih rendahnya kemampuan renang gaya dada baik sewaktu dalam perkuliahan maupun pada saat penelitian pengambilan penilaian renang gaya dada 200 meter, mahasiswa banyak yang tidak mampu berenang gaya dada 200 meter, banyak menghabiskan waktu yang telah ditentukan karena kurangnya kemampuan kondisi fisik mahasiswa yang ada kaitannya dengan rendahnya kemampuan VO2 Max mahasiswa, untuk meningkatkan VO2 Max mahasisiwa haruslah latihan yang dominan berada pada kondisi fisik yang berkaitan daya tahan jantung berguna untuk kemampuan jantung memompa darah sebanyak mungkin, dan latihan daya tahan otot yang bagus juga akan memperkecil hambatan, apabila di kombinasikan dengan latihan teknik.

Berdasarkan dari uraian-uraian tersebut peneliti tertarik untuk membuktikan secara ilmiah tentang VO2 Max dengan renang gaya dada 200 meter. Dari hasil penelitian diharapkan dapat melahirkan suatu kesimpulan yang bisa dijadikan langkah antisipasi bagi peningkatan prestasi renang mahasiswa Fakultas Ilmu Keolahragaan UNP maupun atlet.

\section{KAJIAN TEORI}

Menurut Sumosardjuno (1996) mengatakan. 'VO2 Max menggambarkan tingkat aktivitas badan untuk mendapat oksigen, mengirimkan ke otot, ke sel lain dan menggunakannya dalam pengadaan energi, membuang sisa metabolisme yang menghambat aktivitas fisik'. Pengertian ini bukan saja mengatakan bahwa VO2 Max sebagai tingkat kemampuan badan/fisik untuk mengambil oksigen. Tetapi juga mengirimkan ke otot-otot yang bekerja serta membantu pembuangan sisa metabolisme.Berpedoman pada teori diatas, dapat di katakan bahwa VO2 Max merupakan volume oksigen terbanyak (maksimal) yang dapat dikosumsi tubuh dengan satuan liter/menit yang bertujuan untuk memenuhi tuntutan fisik yang dilakukan dikenal sebagai daya tahan aerobik.

Salah satu renang gaya dada 200 meter, renang yang membutuhkan sistim energi daya tahan aerobic, dimana olahraga yang membutuhkan waktu yang cukup lama, rentang waktu yang dibutuhkan 2 menit keatas. Diperkuat dengan pendapat Bafirman (2008) " olahraga ini terdapat pada kategori daya tahan sedang/ menengah (2 sampai 8 menit) kemampuan ini disebut kapasitas anaerobik 
atau juga dapat dikatakan aerobik. Dimana kemampuan renang gaya dada 200 meter banyak sekali faktor-faktor kondisi fisik yang mempengaruhinya, salah satunya kemampuan VO2 Max dan dimana jantung harus mampu memompa darah ke seluruh tubuh, bicara tentang renang gaya dada 200 meter pastinya kita mengkaitkan sistem energi yang terkandung pada cabang olahraga tersebut yang mempunyai sistem aerobik terdiri dari glikolisis aerobik, dari krebs, dan sistem transport elektron yang terjadid alam mitokondria. Bila oksigen mencukupi maka asam piruvat yang terjadi karena pemecahan glikogen atau glikosa hanya sedikit sekali yang berubah menjadi asam laktat. Bagian terbesar asam piruvat masuk kedalam mitokondria melibatkan sistem enzim yang kompleks.

\section{METODE PENELITIAN}

Sesuai dengan tujuan penelitian maka digunakan metode korelasional. Menurut Sudjana (1996) bahwa "Penelitian korelasi merupakan penelitian untuk mengetahui ada tidaknya hubungan antara variabel yang diteliti, besar atau tingginya hubungan dinyatakan dalam bentuk koefisien korelasi'". Dalam penelitian ini, untuk selanjutnya dicari indeks kontribusi VO2 Max sebagai variabel bebasnya, terhadap kemampuan renang gaya dada 200 meter mahasiswa yang merupakan variabel terikat. Penelitian ini dilaksanakan di kolam teratai Gor H. Agus Salim untuk pengambilan data renang gaya dada 200 meter, sedangkan data VO2 Max mahasiswa diambil di Gor Universitas Negeri Padang. Waktu penelitian ini dilaksanakan pada bulan Mei 2013 sampai Juni 2013. Populasi dalam penelitian ini adalah mahasiswa yang mengambil mata kuliah renang sebanyak 112, untuk mempermudah dalam penelitian maka peneliti mengambil sampel laki-laki 104. Dikarenakan populasi terdiri dari 4 kode seksi maka pengambilan sampel dalam penelitian adalah teknik random. Apabila subjek kurang dari 100, maka lebih baik diambil semuanya, tetapi jika subjekya besar dapat diambil 10-15\% atau 20-25\% atau lebih (Arikunto, 2006). Untuk memudahkan pengolahan data maka sampel diambil 50\% dari tiap-tiap kode seksi. Dengan demikian didapat jumlah sampel dalam penelitian ini sebanyak 54 mahasiswa.

Instrument yang digunakan dalam penelitian ini adalah 1) test VO2 Max menggunakan test bleep test atau tes lari multi tahap, 2) tes renang gaya dada 200 meter diukur dengan waktu (stopwatch). Teknik analisis data menggunakan teknik korelasi produck moment, data yang diperoleh tersebut dianalisis dengan teknik korelasi sederhana, untuk menguji signifikan dari variabel bebas terhadap variabel terikat menggunkan rumus uji t, selanjutnya untuk menghitung besarnya kontribusi VO2 Max terhadap kemampuan renang gaya dada 200 meter menggunakan koefisien determinasi rumus $\mathrm{K}=\mathrm{r}^{2} \mathrm{x} 100 \%$.

\section{HASIL PENELITIAN}

\section{Kemampuan VO2 Max $\left(\mathrm{X}_{1}\right)$}

Berdasarkan hasil tes Kemampuan VO2 Max yang dilakukan, diperoleh skor maksimum $=45,9$ dan skor minimum $=26,2$ dan diperoleh nilai mean (rata-rata) Kemampuan VO2 Max $=35,84$. Agar lebih jelasnya data tes Kemampuan VO2 Max dapat dilihat pada tabel di bawah ini: 
Tabel 1

Distribusi Frekuensi Kemampuan VO2 Max $\left(\mathrm{X}_{1}\right)$

\begin{tabular}{cccc}
\hline \multirow{2}{*}{ No } & Kelas Interval & \multicolumn{2}{c}{ Frekuensi } \\
\cline { 3 - 4 } & & Absolut $(\mathbf{F a})$ & Relatif $(\boldsymbol{\%})$ \\
\hline 1 & $>38,6-41,6$ & 11 & 20,37 \\
\hline 2 & $35,5-38,5$ & 14 & 25,92 \\
\hline 3 & $32,4-35,4$ & 22 & 40,74 \\
\hline 4 & $29,3-32,3$ & 3 & 5,55 \\
\hline 5 & $<26,2-29,2$ & 4 & 7,40 \\
\hline & Jumlah & 54 & $100 \%$ \\
\hline
\end{tabular}

Berdasarkan tabel distribusi frekuensi Kemampuan VO2 Max di atas dari 54 orang sampel, diperoleh 11 orang sampeldengan persentase 20,37\% memiliki Kemampuan VO2 Max berkisar >38,6, 14orang sampel dengan persentase 25,92\% memiliki tingkat Kemampuan VO2 Max berkisar antara 35,5-38,5, 22 orang sampel dengan persentase 40,74\% memilikitingkat Kemampuan VO2 Max berkisar antara 32,4-35,4, 3 orang sampel dengan persentase 5,55\% memiliki tingkat Kemampuan VO2 Max berkisar antara 29,3-32,3, dan 4 orang sampel dengan persentase 7,40\% memiliki tingkat Kemampuan VO2 Max berkisar antara 29,2-29,2. Berdasarkan nilai rata-rata kemampuan VO2 Max berada pada kelas interval 35,5-38,5. dapat dilihat pada histogram dibawah ini :

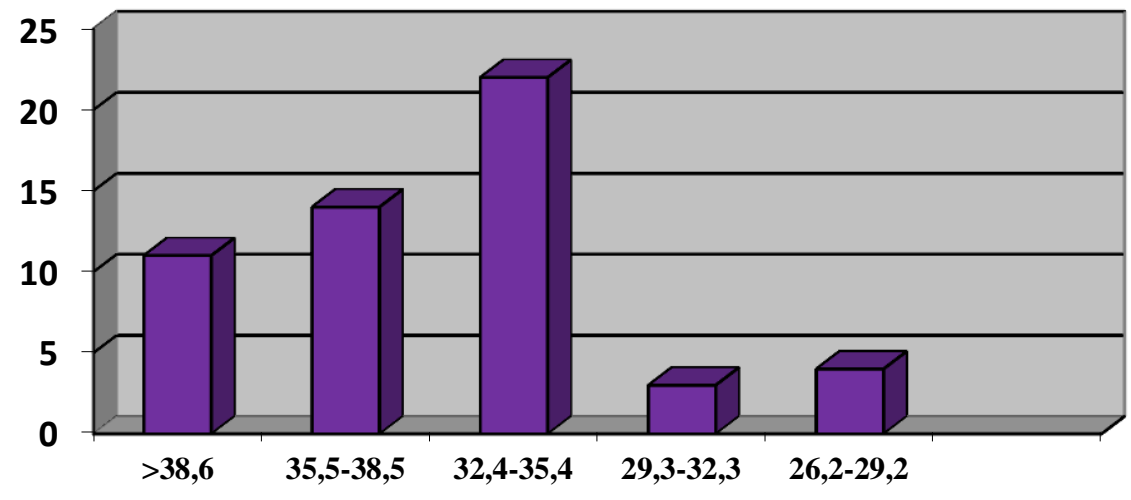

Gambar 1.Histogram Kemampuan $\operatorname{VO2} \operatorname{Max}\left(\mathrm{X}_{1}\right)$

\section{Kemampuan Renang Gaya Dada 200 M (Y)}

Berdasarkan hasil tes Kemampuan Renang Gaya Dada 200 meter diperoleh skor maksimum 3,10 dan skor minimum8,37, dan diperolehnilairatarata 5,03. Agar lebih jelasnya deskripsi data Kemampuan Renang Gaya Dada 200 meter tersebut dapat dilihat pada tabel distribusi frekuensi dibawah ini : 
Tabel 2

Distribusi Frekuensi Kemampuan RenangGaya Dada 200 M (Y)

\begin{tabular}{cccc}
\hline \multirow{2}{*}{ No } & \multirow{2}{*}{ Kelas Interval } & \multicolumn{2}{c}{ Frekuensi } \\
\cline { 3 - 4 } & & Absolut (Fi) & Relatif(\%) \\
\hline 1 & $>3,90-4,69$ & 25 & $46,29 \%$ \\
\hline 2 & $4,70-5,49$ & 18 & $33,33 \%$ \\
\hline 3 & $5,50-6,29$ & 6 & $11,11 \%$ \\
\hline 4 & $6,30-7,09$ & 4 & 7,40 \\
\hline 5 & $<7,10-7,89$ & 1 & $1,85 \%$ \\
\hline & Jumlah & 54 & $100 \%$ \\
\hline
\end{tabular}

Berdasarkan tabel distribusi frekuensi kemampuan renang gaya dada 200 meter diatas dari 54 orang sampel, 25 orang dengan persentse 46,29\% memiliki tingkat Kemampuan Renang Gaya Dada 200 Meter berkisar >3,90-4,69, 18 orang dengan persentse 33,33\% memiliki tingkat Kemampuan Renang Gaya Dada 200 Meter berkisar 4,70-5,49,6 orang dengan persentase 11,11\% memiliki tingkat Kemampuan Renang Gaya Dada 200 Meter berkisar 5,50-6,29, 4 orang dengan persentase 7,40\% memiliki tingkat Kemampuan Renang Gaya Dada 200 Meter berkisar antara 6,30-7,09dan 1 orang dengan persentase 1,85\% dengan tingkat Kemampuan Renang Gaya Dada 200 Meter berkisar <7,10-7,89. Berdasarkan nilai rata-rata dari hasil pengukuran Kemampuan Renang Gaya Dada 200 Meter diperoleh sebesar 5,03, jadi dapat disimpulkan bahwa kemampuan Kemampuan Renang Gaya Dada 200 Meter berada pada pada kelas interval 5,50-6,-29.

Untuk lebih jelasnya distribusi frekuensi Kemampuan Renang Gaya Dada $200 \mathrm{M}$ diatas juga dapat di lihat pada histogram di bawah ini:

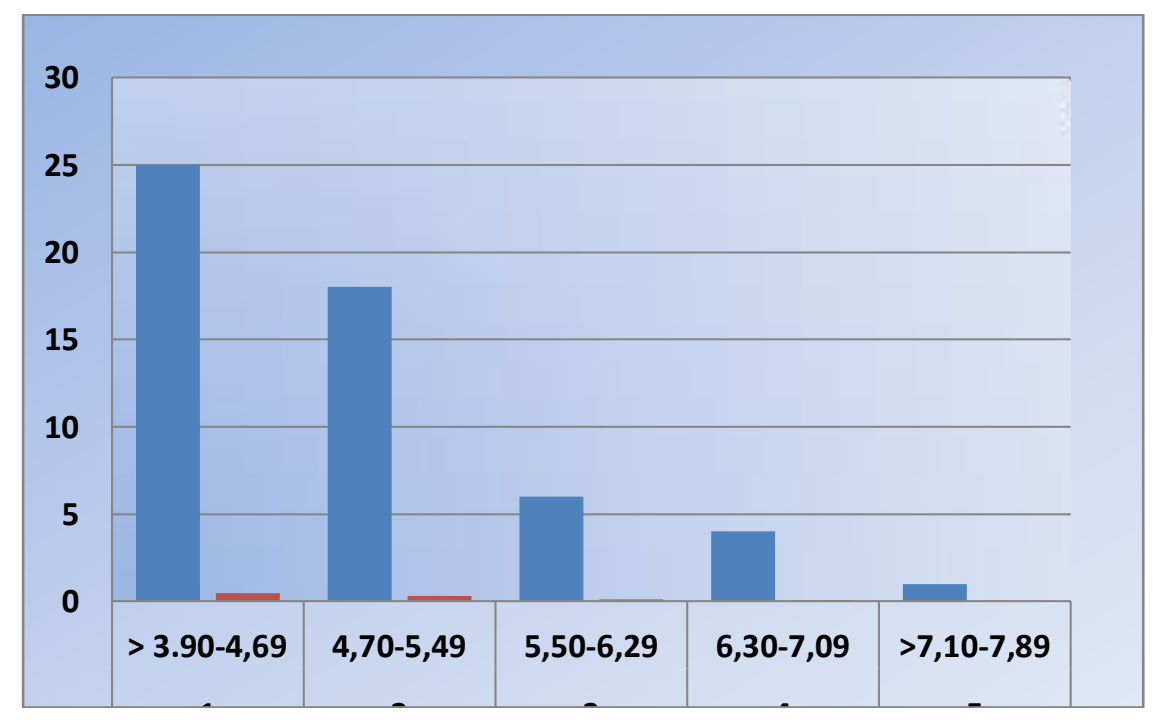

Gambar 2 Histogram Kemampuan Renang Gaya Dada 200 M (Y) 
Berdasarkan hasil penelitian ini terdapatnya variabel bebas dengan variabel terikat berdistribusi normal dengan Hasil pengujian normalitas.

Tabel 3

Hasil Pengujian Normalitas Data

\begin{tabular}{llcrcc}
\hline No & Variabel & $\mathbf{N}$ & $\mathbf{L}_{\mathbf{0}}$ & $\mathbf{L}_{\text {tab }}$ & Distribusi \\
\hline 1 & Kemampuan VO2 Max $\left(\mathbf{X}_{\mathbf{1}}\right)$ & 54 & 0.1056 & 0.1206 & Normal \\
\hline 2 & Renang Gaya Dada 200 M $(\mathbf{Y})$ & 54 & 0.1205 & 0.1206 & Normal \\
\hline
\end{tabular}

Berdasarkan tabel di atas menunjukan bahwa hasil penelitian untuk pengujian

1. Tes kemampuan VO2 $\operatorname{Max}(\mathrm{X} 1)$ skor Lo $=0.1056$ dengan $\mathrm{n}=54$, sedangkan Ltab pada taraf pengujian signifikan $\alpha=0,05$ diperoleh 0,1206 yang lebih besar dari Lo sehingga dapat disimpulkan bahwa skor yang diperoleh dari tes Kemampuan VO2 Max berdistribusi normal.

2. Sedangkan untuk hasil uji normalitas tes Renang Gaya Dada 200 M(Y) diperoleh skor Lo $=0.1205$ dengan $\mathrm{n}=54$, sedangkan Ltab pada taraf pengujian signifikan $\alpha=0,05$ diperoleh 0,1206 yang lebih besar dari Lo sehingga dapat disimpulkan bahwa skor yang diperoleh dari tes Renang Gaya Dada 200 M berdistribusi normal.

3. Maka dari hasil uraian diatas kita bisa menilai, semua variabel tersebar secara normal, karena masing-masing variabel skor Lo nya lebih kecil dari pada Ltab pada taraf pengujian signifikan $\alpha=0,05$

Ho = tidak terdapat hubungan serta kontribusi yang signifikan antara VO2 Max terhadap renang gaya dada 200 meter. $\mathrm{Ha}=$ terdapat hubungan serta kontribusi yang signifikan antara VO2 Max terhadap renang gaya dada 200 meter.

Berdasarkan hasil penelitian ini adalah terdapat kontribusi yang berarti (signifikan) antara $\mathrm{Vo}_{2}$ maks terhadap renang gaya dada 200 meter. hal ini terlihat bahwa dari analisis statistik yang dilakukan diperoleh $r$ hitung sebesar 0,382 dan $r$ tabel dalam taraf $\alpha=0,05$ sebesar 0.261 dengan demikian rhitung $(0,382)>$ rtabel (0,261). Ini berarti terdapat hubungan yang berarti antara VO2 Max terhadap renang gaya dada 200 Meter. Dari hasil $r$ hitung 0,382 bisa mencari hasil kontribusi, maka dari hasil analisis penelitian yang dilakukan dimana diperoleh $\mathrm{K}=0.382^{2} \times 100 \%=14,59 \%$, jadi dapat disimpulkan bahwa variabel bebas VO2 Max berkontribusi terhadap renang gaya dada $200 \mathrm{M}$ sebesar 14,59\%. Oleh karena itu hipotesis dalam penelitian ini diterima kebenarannya secara empiris.

Tabel 4

Hasil Penelitian

\begin{tabular}{lccc}
\hline \multicolumn{1}{c}{ Korelasi } & $\begin{array}{c}\text { Koefisien } \\
\text { korelasi } \\
(\mathbf{r})\end{array}$ & $\begin{array}{c}\text { Koefisien } \\
\text { Determinasi } \\
\left(\mathbf{r}^{\mathbf{2}} \mathbf{1 0 0 \%}\right)\end{array}$ & $\begin{array}{c}\text { Taraf Signifikan } \\
\boldsymbol{\alpha}=\mathbf{0 , 0 5}\end{array}$ \\
\hline $\begin{array}{l}\mathrm{Vo}_{2} \text { maks terhadap } \\
\text { renang gaya dada } 200\end{array}$ & 0,382 & 14,59 & 0,261 \\
Meter & & & \\
\hline
\end{tabular}


Berdasarkan hasil penelitian yang telah dilakukan, maka terdapatnya kontribusi antara VO2 Max terhadap renang gaya dada 200 meter, tetapi dilihat dari hasil kontribusi $14,59 \%$ masih banyak kekurangan-kekurangan yang terjadi seharusnya dilihat juga kemampuan VO2 Max masih rendah, teknik latihan, komposisi tubuh yang tidak ideal, indeks masa tubuh tidak ideal, juga kemampuan gerak motorik mahasiswa renang. Untuk yang keseskiankalinya yang harus diperhatikan baik dari instruktur renang maupun dari mahasiswa renang tersebut, mahasiswa akan bisa mendapatkan hasil kemampuan renang gaya dada 200 meter yang bagus, apabila mahasiswa sendiri mau latihan kondisi fisik yang berkaitan dengan renang gaya dada 200 meter, dimana latihan daya tahan yang berguna melatih fungsi fisiologi jantung agar meningkatnya kemampuan VO2 Max.

Menurut Pate (1999) menyatakan faktor-faktor yang mempengaruhi VO2 Max adalah: 1) fungsi paru jantung, tidak dapat menggunakan oksigen lebih cepat dari pada sistem paru-jantung dalam menggerakan oksigen kejaringan yang aktif.Ini merupakan faktor penentu VO2 Max. 2) kegemukan badan, jaringan lemak menambah berat badan tetapi tidak mendukung kemampuan seseorang untuk secara lansung menggunakan oksigen selama olahraga berat. 3) keadaan latihan, kebiasaan kegiatan dan latar belakang latihan seseorang dapat mempengaruhi nilai VO2 Max. 4) keturunan, kebanyakan penelitian menunjukkan bahwa besarnya peningkatan itu terbatas dari 10-20\%, gambaran ini menganggap rendah peningkatan yang terjadi dalam program jangka panjang untuk latihan dengan itensitas tinggi. Meskipun demikian jelas bahwa VO2 Max seseorang/perorangan dapat berbeda karena perbedaan garis keturunan.

Dan juga yang sangat membantu latihan daya tahan otot dan latihan teknik yang berguna memperkecil hambatan. Dimana diperkuat oleh pendapat Syafruddin, (2004) latihan teknik yang tepat adalah salah satu penunjang untuk menjadi juara, karena dengan teknik yang benar dapat memperkecil hambatan. Seseorang yang sering latihan akan memiliki daya tahan yang baik jika dibandingkan dengan orang yang kurang latihan. Seseorang yang rutin beraktifitas akan cepat beradaptasi terhadap beban yang diberikan saat latihan atau beraktifitas, termasuk kerja jantung dan paru juga akan terbiasa dengan beban yang dilakukan. Kerja jantung dan paru akan lebih optimal dalam memompakan darah keseluruh tubuh sehingga kapasitas VO2 Max juga akan meningkat.

Menurut Harsono (1988) "latihan yang dilakukan secara teratur serius dan sistematis sesuai dengan program yang telah dibuat mampu memberi efek yang signifikan terhadap otot-otot yang terlibat dalam pelaksanaan latihan". Kapasitas otot fast twitch dan slow twitch akan menigkat sesuai dengan karakteristik kedua tipe serabut otot". Latihan yang efektif juga memberi efek pada jantung. Sebab jantung merupakan organ tubuh yang berperan penting memompakan ke seluruh tubuh. Ukuran jantung mahasiswa olahraga yang terlatih lebih besar akibat adaptasi dari latihan begitu juga dengan curah jantung dan stroke volume akan lebih besar, begitupun dengan peningkatan denyut nadi akan lebih lambat dan pada saat pemulihan, penurunan denyut nadi akan lebih cepat sehingga semakin cepat pula pulihnya kondisi fisik seorang mahasiswa olahraga, dengan kata lain daya tahannya lebih baik. 


\section{PEMBAHASAN}

Berdasarkan penelitian yang telah dilakukan, aspek yang dinilai dalam pelaksanaan tes adalah peserta tes mengikuti petunjuk kaset bleep test dengan ketentuan berapa level yang mereka tempuh dan berapa balikan dari level terakir yang dapat mereka lakukan, maka diperoleh hasil bahwa tingkat VO2 Max mahasiswa Jurusan Kesehatan dan Rekreasi setelah dilakukan tes bleep test dari 54 orang.

Dalam pembahasan ini yang akan dilihat berdasarkan hasil dari penelitian yang dilakukan dengan prosedur uji statistik. Mengikuti petunjuk kaset bleeptest dengan ketentuan beberapa level terakhir yang dapat mereka lakukan.Hal ini dapat dibuktikan dengan hasil yang didapat dalam penelitian, dimana samakin tinggi tingkat kebiasaan latihanmaka semakin tinggi pula tingkat VO2 Maxnya dan kemampuan berenang dan lebih baik lagi untuk meningkatkan kondisi fisiknya, gizi yang tidak seimbang dan istirahat yang kurang teratur menyebabkan tingkat kemampuan volume oksigen maksimal rendah.

Hasil dari penelitian yang telah dilaksanakandi lapangan membuktikan bahwa terdapat kontribusi dari variable VO2 Maxterhadap renang gaya dada 200 M mahasiswa Jurusan Kesehatan Rekreasi FIK UNP. Hal ini di buktikan berdasarkan hasil uji hipotesis menunjukkan bahwa terdapat hubungan antara variabel VO2 Max terhadap renang gaya dada $200 \mathrm{M}$ dengan hasil $r_{\text {hitung }}(0,382)>r$ tabel $(0,261)$. Setelah itu untuk membuktikan keberartian (signifikansi) antara ke dua variabel dilakukan uji $t$ dengan hasil $t_{\text {hitung }}(3,24)>t_{\text {tab }}(1,675)$, sehingga dapat disimpulkan terdapat hubungan yang signifikan antara ke dua variabel. Kemudian untuk mengetahui seberapa besar kontribusi VO2 Max terhadap renang gaya dada $200 \mathrm{M}$ dapat diketahui dari hasil analisis yang dilakukan dimana diperoleh $\mathrm{K}=$ $0.382^{2} \times 100 \%=14,59 \%$, jadi dapat disimpulkan bahwa variabel bebas VO2 Max berkontribusi terhadap renang gaya dada $200 \mathrm{M}$ sebesar 14,59\%. Dilihat dari hasil kontribusi VO2 Max terhadap kemampuan renang gaya dada 200 meter jauh dari sempurna yang hasil kekurangannya sampai $85,41 \%$ dimana faktor-faktor yang harus dilihat juga kemampuan teknik latihan, komposisi tubuh yang sempurna, bentuk postur tubuh yang bagus, indeks masa tubuh, dan juga kemampuan gerak motorik mahasiswa renang. Dilihat dari hasil penelitian data nilai VO2 Max mahasiswa yang berjumlah 54 orang memiliki nilai rata-rata 35,84 dihubungkan dengan klasifikasi VO2 Max untuk putra, mahasiswa memiliki klasifikasi cukup.

Dengan tingkat kontribusi yang cukup ini tentu harus disikapi oleh pelatih atau dosen maupun mahasiswa renang dengan baik, karena dengan penelitian ini kita semua dapat mengetahui bahwa unsur latihan kondisi fisik sangat membantu dalam mengembangkan kemampuan renang gaya dada 200 meter dan juga harus hendaknya terus dikembangkan di dalam program latihan yang akan dilaksanakan oleh mahasiswa pada waktu melakukan perkuliahan renang. Pada umumnya dari realita yang terjadi selama ini dikolam,pelatih atau dosen memberikan latihan lebih diperioritaskan kepada teknik,dan bentuk-bentuk latihan kondisi fisik yang sangat berkaitan kepada kemampuan renang gaya dada 200 meter. Dengan demikian tentu mahasiswa atau atlet renang hanya memperoleh kematangan di segi teknik, dan latihan kondisi fisik, artinya pelatih ataupun atlet tidak lupa akan pentingnya kondisi fisik di dalam pengembangkan teknik, dan kondisi fisik yang sudah dilatih.Salah satu dari unsur-unsur kondisi fisik yaitu daya tahan aerobik yang di tes melalui VO2 Max yang cukup berarti memberikan kontribusi terhadap 
renang gaya dada 200 Meter mahasiswa Jurusan Kesehatan dan Rekreasi FIK UNP.

Menurut Pate (1993) "VO2 Max merupakan kapasitas volume oksigen maksimal (VO2 Max) adalah tempo tercepat dimana seseorang dapat menggunakan oksigen selama olahraga". VO2 Max yang besar berbanding lurus dengan kemampuan seorang mahasiswa olahraga memikul beban kerja yang berat dan dalam waktu yang relatif lama. Hal ini disebabkan kapasitas anaerobik yang dimiliki seseorang mahasiswa olahraga sangat terbatas, sehingga sulit untuk bertahan dalam memikul beban kerja atau latihan yang berat dengan hanya mengandalkan sistem anaerobik saja yaitu tanpa menggunakan oksigen apalagi dalam waktu yang cukup lama. Oleh sebab itu sistem aerobik yang bekerja hanya dengan pemakaian oksigen merupakan kunci penentu keberhasilan dalam olahraga ketahanan. VO2 Max yang berat juga mempercepat pemulihan setelah beraktivitas. Hal ini sejalan dengan pendapat Saltin dalam Bafirman (1996) yang menyatakan "volume oksigen maximal merupakan salah satu faktor penting untuk menunjang prestasi atlet, lebih-lebih pada atlet dari cabang olahraga yang termasuk olahraga daya tahan (enduranceevent)".

Telah dijelaskan diatas bahwa VO2 Max yang tinggi memungkinkan untuk melakukan pengulangan gerakan yang berat dan lebih lama, dibedakan bila VO2 Maxnya rendah untuk dasar aktifitas fisik yang sama, maka VO2 Max yang lebih tinggi akan menghasilkan kadar asam laktat rendah, ini adalah salah satu penyebab kenapa seseorang yang memiliki VO2 Max yang tinggi lebih cepat pemulihannya setelah beraktifitas atau latihan jika dibedakan dengan seseorang yang VO2 Maxnya rendah.

Suatu pemulihan yang cepat akan membawa seseorang untuk mengurangi interval istirahat dan melakukan kerja dengan itensitas yang lebih tinggi. Ini sebagai hasil dari interval istirahat yang pendek (cepat pemulihan) sehingga jumlah repitisi dapat dinaikkan, dan ini merupakan suatu tambahan dalam volume latihan. Bagaimanapun juga, VO2 Max mengandalkan pada sistem respirasi dan pernapasan yang benar. Pernapasan memainkan peranan yang sangat penting dalam latihan daya tahan terutama pada olahraga yang membutuhkan waktu yang cukup lama dengan jumlah pengulangan keterampilannya tinggi.

Seseorang yang rutin beraktifitas atau berlatih akan memiliki daya tahan yang lebih baik jika dibandingkan dengan orang yang kurang beraktifitas. Seseorang yang rutin beraktifitas atau berlatih akan cepat beradaptasi terhadap beban yang diberikan saat berlatih atau beraktifitas, termasuk kerja jantung dan paru juga akan terbiasa dengan beban yang dilakukan. Kerja jantung dan paru akan lebih optimal dalam memompakan darah keseluruh tubuh sehingga kapasitas VO2 Max juga akan meningkat.

Menurut Harsono (1996) "latihan yang dilakukan secara teratur serius dan sistematis sesuai dengan program yang telah dibuat mampu memberi efek yang signifikan terhadap otot-otot yang terlibat dalam pelaksanaan latihan". Kapasitas otot fast twitch dan slow twitch akan menigkat sesuai dengan karakteristik kedua tipe serabut otot". Latihan yang efektif juga memberi efek pada jantung. Sebab jantung merupakan organ tubuh yang berperan penting memompakan ke seluruh tubuh. Ukuran jantung mahasiswa olahraga yang terlatih lebih besar akibat adaptasi dari latihan begitu juga dengan curah jantung dan stroke volume akan lebih besar, begitupun dengan peningkatan denyut nadi akan lebih lambat dan 
pada saat pemulihan, penurunan denyut nadi akan lebih cepat sehingga semakin cepat pula pulihnya kondisi fisik seorang mahasiswa olahraga, dengan kata lain daya tahannya lebih baik.

Tinggi rendahnya daya tahan seseorang dipengaruhi oleh kemampuan mengambil oksigen yang dibutuhkan oleh tubuh. Dapat dikemukakan bahwasemakin tinggi tingkat intensitas mahasiswa terhadap latihan dalam sehari, maka semakin tinggi pula hasil kemampuan VO2 Max yang mereka peroleh.

Sebetulnya, kemampuan VO2 Max mahasiswa dapat ditingkatkan melalui latihan-latihan yang teratur terutama bersifat aerobik karena dapat menyebabkan seseorang bernafas lebih cepat dan lebih dalam yang dapat memberikan dampak pada kerja jantung dan paru lebih efisien serta pembuluh darah menjadi lebih lebar yang dapat mempelancar jalan sirkulasi darah.

\section{SIMPULAN}

Adapun simpulan mengenai kontribusi VO2 Max terhadap kemampuan renang gaya dada 200 meter, yakni sebagai berikut: terdapat perbandingan $\mathrm{r}_{\text {hitung }}$ $(0,382)>r_{\text {tabel }}(0,261)$ yang menunjukkan terdapat hubungan antara VO2 Max dengan kemampuan renang gaya dada 200 meter. Dilihat hasil $t_{\text {hitung }}(3,24)>t_{\text {tab }}$ $(1,675)$, yang menunjukkan terdapat hubungan yang signifikansi antara VO2 Max dengan kemampuan renang gaya dada 200 meter. Terdapatnya kontribusi VO2 Max terhadap kemampuan renang gaya dada 200 meter mahasiswa Jurusan Kesehatan Rekreasi FIK UNP dengan tingkat persentase sebesar 14,59\%.

\section{DAFTAR PUSTAKA}

Arikunto, S. (2006). Prosedur Penelitian. Jakarta : PT Rekina Cipta

Arsil. (1999). Pembinaan Kondisi Fisik. Padang : FIK UNP

Bafirman. (2008). Pembentukan Kondisi Fisik. FIK UNP

Harsono. (1996). Prinsip-prinsip Pelatihan. Jakarta : PIO-KONI Pusat

Pate. (1993). Dasar-dasar Ilmiah Kepelatihan. IKIP Semarang Press

Sumosardjuno. (1996). Sehat dan Bugar. Jakarta : PT Gramedia

Sudjana. (1996). Teknik Analisis Regresi dan Korelasi. Bandung : UNPAD

Syafruddin. (2004). Pengetahuan Training Olahraga. Padang : FIK UNP

Undang-undang Republik Indonesia. 2005. Sistem Keolahragaan Nasional. Jakarta : Bandung 